DOI: https://doi.org/10.47405/mjssh.v5i10.513

\begin{tabular}{|c|c|}
\hline 1. 1.54 & Malaysian Journal of Social Sciences and Humanities (MJSSH) \\
\hline $\begin{array}{c}\text { Malaysian Journal of } \\
\text { solal sciences and }\end{array}$ & Volume 5, Issue 10, October 2020 \\
\hline (MJ-SSH) & e-ISSN : 2504-8562 \\
\hline & $\begin{array}{l}\text { Journal home page: } \\
\text { www.msocialsciences.com }\end{array}$ \\
\hline
\end{tabular}

\title{
Kesediaan Guru dan Pelajar Terhadap Penggunaan Pembelajaran Mobil dalam Pembelajaran dan Pemudahcaraan (PdPc): Sorotan Literatur Bersistematik
}

\author{
Thian Jia Ling1, Mohd Effendi @ Ewan Mohd Matore1 \\ 1Fakulti Pendidikan, Universiti Kebangsaan Malaysia (UKM) \\ Correspondence: Mohd Effendi @ Ewan Mohd Matore (effendi@ukm.ed.my)
}

\begin{abstract}
Abstrak
Pembelajaran mobil bermaksud persekitaran pembelajaran yang berlaku di pelbagai lokasi dengan jangka masa yang tidak terhad dan terdiri daripada bahan pembelajaran yang tidak terkira dari pelbagai sumber melalui alat mudah alih seperti tablet atau telefon pintar. Sorotan literatur bersistematik ini dibuat bertujuan untuk mengkaji kesediaan guru dan pelajar terhadap penggunaan pembelajaran mobil dari aspek kesediaan asas, kesediaan kemahiran, kesediaan psikologi dan kesediaan perbelanjaan. Dapatan kajian menunjukkan bahawa majoriti guru dan pelajar mempunyai teknologi mudah alih dan bersedia untuk menjalankan pembelajaran mobil. Mereka juga mempunyai kemahiran mengaplikasikan teknologi mudah alih bagi melakukan aktiviti pembelajaran. Kebanyakan guru dan pelajar mempunyai kesediaan psikologi yang positif terhadap penggunaan pembelajaran mobil. Walau bagaimanapun, terdapat sebahagian pelajar yang berasa tidak selesa dan tidak selamat mengenai kaedah pembelajaran mobil kerana mudah terdedah kepada isu pengintipan maklumat. Selain itu, terdapat pelajar yang kurang bersedia dari segi kewangan bagi menanggung kos tambahan seperti kos data mobil untuk pembelajaran. Tidak dapat disangkalkan bahawa pembelajaran mobil masih sangat baru dan belum berkembang menjadi matang. Maka, penggunaan pembelajaran mobil dalam bidang pendidikan seharusnya dirancang dan dilaksanakan dengan berhati-hati.
\end{abstract}

Kata kunci: pembelajaran mobil, kesediaan guru dan pelajar, teknologi mudah alih

\section{Teachers and Students' Readiness Towards the Application of Mobile Learning in Teaching and Learning (T\&L): Systematic Literature Review}

\begin{abstract}
Mobile learning means a learning environment that takes place in various locations with an unlimited amount of time and consists of countless learning materials from various sources through the use of mobile devices such as tablets or smartphones. The aim of this systematic literature review is to study the readiness of teachers and students towards the use of mobile learning in terms of basic readiness, skills readiness, psychological readiness and spending readiness. The findings of the study show that most of the teachers and students have mobile technology and are ready to conduct mobile learning. They also have the skills to apply mobile technology to do learning activities. Majority teachers and students have positive psychological readiness towards the use of mobile learning. However, there are some students who feel uncomfortable and insecure to learn using mobile technology because they are easily exposed to information spying issues. In addition, there are students who are less financially prepared to bear additional costs such as the cost of mobile data for learning. It cannot be denied
\end{abstract}


anymore that moile learning is still very new and has not yet developed into mature. Therefore, the use of mobile learning in the field of education should be carefully planned and implemented.

Keywords: mobile learning, teachers and students' readiness, mobile technology

\section{Pengenalan}

Pelan Pembangunan Pendidikan Malaysia (PPPM) 2013-2025 telah menyatakan hasrat kementerian dalam memanfaatkan teknologi maklumat dan informasi untuk meningkatkan kualiti pembelajaran negara kita. Ia bertindak sebagai platform Kementerian Pendidikan untuk menghasilkan tenaga kerja yang celik teknologi, berfikir secara kritis, bersedia untuk melibatkan diri dengan sepenuhnya dalam ekonomi global abad ke-21 (Ghavifekr \& Mohammed Sani 2015). Ia juga berperanan sebagai pemacu bagi mencapai Wawasan 2020 Malaysia untuk menjadikan Malaysia sebagai peneraju teknologi maklumat dan komunikasi di peringkat antarabangsa (Ghavifekr et al. 2016). Sehubungan dengan itu, Kurikulum Standard Sekolah Rendah (KSSR) semakan 2017 oleh Kementerian Pendidikan Malaysia (KPM) telah menekankan kepentingan menerapkan penggunaan teknologi maklumat dan komunikasi dalam aktiviti pembelajaran dan pemudahcaraan. Pengaplikasian teknologi maklumat dan komunikasi bukan sahaja mendorong pelajar menjadi kreatif, malah menjadikan aktiviti penimbaan ilmu pengetahuan dalam kalangan pelajar-pelajar lebih menarik dan menyeronokkan (KPM 2016).

Berikutan dengan perkembangan dan kemajuan teknologi maklumat dan komunikasi yang pesat serta berterusan, lebih banyak tumpuan telah diberi kepada penembusan dan pemilikan peranti mudah alih pada masa kini berbanding dengan pembelian komputer desktop pada dua dekad yang lalu. Hasil survei Suruhanjaya Komunikasi dan Multimedia Malaysia (2018) melaporkan bahawa telefon pintar merupakan peranti yang paling popular digunakan untuk mengakses Internet di mana sembilan dari sepuluh pengguna Internet menggunakan telefon pintar (93.1\%) untuk mengakses ke dalam talian. Fenomena ini telah menarik perhatian para pendidik terhadap potensi teknologi mudah alih, khususnya telefon pintar sebagai alat bantu belajar untuk diintegrasikan dalam proses pembelajaran dan pemudahcaraan $(\mathrm{PdPc})$. Hal ini demikian disebabkan oleh teknologi mudah alih dipercayai dapat menawarkan pelbagai peluang untuk menyampaikan pembelajaran melalui kaedah yang inovatif dan menarik di dalam dan di luar kelas (Almutairy, Davies \& Dimitriadi 2015) kerana ciri-ciri keunikannya seperti mobiliti, keberadaan, kebolehcapaian dan privasi (Arlina Ahmad Zaki \& Melor Yunus 2015).

\section{Sorotan Literatur}

Dalam pada itu, proses PdPc yang dijalankan dengan menggunakan teknologi mudah alih dikenali sebagai pembelajaran mobil atau m-pembelajaran. Pembelajaran mobil merujuk kepada persekitaran pembelajaran yang berlaku di pelbagai lokasi dengan jangka masa yang tidak terhad dan terdiri daripada bahan pembelajaran yang tidak terkira dari pelbagai sumber melalui alat mudah alih seperti tablet atau telefon pintar (Hafiza Abas, Faridah Hanim Yahya \& Mahamsiatus Kamaruddin (2015). Dalam erti kata lain, pembelajaran dilaksanakan dengan pengaplikasian teknologi mobil dapat menyediakan pembelajaran secara seamless, ubiquitous dan context-aware seterusnya dapat dilaksanakan di mana-mana dan bila-bila masa sahaja (Nurul Aisyah Kamrozzaman, Jamaludin Badusah \& Wan Muna Ruzanna Wan Mohammad 2019) tanpa wayar. Teknologi mobil bukan sahaja mengandungi beraneka fungsi yang boleh dilakukan sama seperti dengan memanipulasikan komputer riba dan komputer untuk mengikuti e-pembelajaran, malah ia juga mudah dibawa dalam poket sehingga pembelajaran dengan mengaplikasikan teknologi mobil ini kadang-kala juga dinama sebagai pembelajaran dalam poket (Khoo \& Fitzgerald 2015).

Kesediaan adalah kesanggupan atau kerelaan (Kamus Dewan Edisi Keempat 2007) untuk melakukan aktiviti tertentu. Chen et al. (2017) menyatakan bahawa penggunaan teknologi mudah alih yang berkesan lebih kurang mengenai alat dan lebih banyak mengenai kemahiran literasi digital pelajar, termasuk kemampuan untuk mengakses, mengurus dan menilai sumber digital. Namun, beberapa 
kajian lepas telah menunjukkan bahawa kebanyakan pelajar enggan menggunakan teknologi mudah alih untuk tujuan pendidikan dan mereka lebih suka menggunakannya untuk rangkaian sosial (Murugan, Teoh \& Liau 2017). Buktinya, kedua-dua kajian Reddy et al. (2016) dan kajian Moosavi, Dewitt \& Naimie (2018) mendapati majoriti pelajar menggunakan teknologi mudah alih untuk memperoleh hiburan, misalnya mendengar lagu dan menonton video. Impaknya, pelajar tidak berupaya dan tidak berpengalaman untuk mengendalikan sumber digital yang dicapai di mana kajian Murugan, Teoh dan Riau (2017) mendapati pelajar tidak pandai membuat, menghasil, berkongsi dan menyemak semula bahan-bahan dari internet.

Tidak boleh dinafikan bahawa guru-guru merupakan kunci kepada kejayaan penerapan teknologi (Papadakis 2018) serta watak utama untuk melaksanakan m-pembelajaran dan melibatkan pelajar mereka dengan menggunakan pedagogi yang relevan (Miglani \& Awadhiya 2017). Rung, Wamke dan Mattheos (2014) telah menegaskan kepentingan untuk memahami kemahiran pengguna utama dan sikap mereka terhadap alat baru untuk memandu perkembangan inovasi yang sesuai. Maka, dalam konteks pendidikan, para pendidik harus mengenal pasti kesediaan pelajar dari aspek pengetahuan dan kemahiran sebelum menerapkan penggunaan teknologi mudah alih dalam proses PdPc. Selain itu, kajian Ahmad Sobri, Muhammad Nidzam Yaakob dan Azizah Sarkowi (2018) menunjukkan bahawa kesediaan memberi pengaruh yang signifikan terhadap penggunaan pembelajaran mobil dalam kalangan pensyarah di Institusi Pendidikan Guru Zon Utara. Jadi, kesediaan pendidik untuk mengaplikasikan teknologi mudah alih dalam usaha menjalankan pembelajaran mobil juga tidak boleh dipandang remeh. Pendek kata, kesediaan guru dan pelajar terhadap penggunaan pembelajaran mobil dalam PdPc merupakan objektif utama yang hendak diteliti dan dikaji dalam kajian ini terutama bagi melihat pola perkembangannya berdasarkan kajian-kajian lepas. Justeru itu, kajian ini bertujuan untuk mengkaji sejauh manakah kesediaan guru dan pelajar terhadap penggunaan pembelajaran mobil dalam PdPc?

\section{Metod Kajian}

Kajian ini hanya mengambil kira artikel jurnal yang diterbit pada tahun 2014 hingga tahun 2020. Hal ini kerana pengkaji mendapati bahawa bilangan artikel kajian berkaitan kesediaan dalam penggunaan pembelajaran mobil yang dihasilkan dalam lingkungan lima tahun terkini, iaitu dari tahun 2016 hingga tahun 2020 adalah terhad dan tidak banyak. Maka, pengkaji memanjangkan kriteria tempoh masa penenrbitan artikel dengan memilih juga terbitan artikel pada tahun 2014 dan tahun 2015. Pengkaji menggunakan kaedah PRISMA untuk menganalisis artikel-artikel jurnal yang dikumpul. Terdapat empat langkah dalam PRISMA yang mengandungi pengenalpastian (identification), pemeriksaan (screening), kelayakan (eligibility) dan terpilih (inclusion). Kaedah ini dipilih kerana ia dapat membantu pengkaji mensintesis artikel jurnal yang relevan. Rajah 1 memaparkan carta aliran PRISMA dalam kajian ini yang diadaptasi dan diubahsuai daripada Moher et al. (2009).

\section{Pengenalpastian (Identification)}

Artikel-artikel dikumpul melalui pangkalan data Google Scholar dan Eric. Kata kunci "kesediaan dalam pembelajaran mobil" dan "kesediaan menggunakan telefon mobil" dalam Bahasa Melayu serta "mobile learning readiness" dan "readiness to use mobil phone" dalam Bahasa Inggeris telah digunakan untuk tujuan pencarian data. Hasilnya, terdapat sebanyak 138 buah artikel jurnal yang dicapai pada peringkat ini.

\section{Pemeriksaan (Screening)}

Pertama sekali, pengkaji hanya memilih artikel berbentuk jurnal, artikel prosiding dan artikel persidangan. Artikel prosiding, manuskrip, kertas kerja persidangan dan sumber rujukan lain tidak dimasukkan dalam kajian ini. Kedua, artikel kajian yang membentangkan kesediaan penggunaan pembelajaran mobil di peringkat pengajian dari sekolah rendah hingga ke pengajian tinggi dipilih kecuali artikel yang dikaji di peringkat prasekolah. Selain itu, pemilihan artikel kajian memfokuskan golongan responden yang terdiri daripada pelajar dan guru termasuk guru pra perkhidmatan kerana mereka merupakan pihak berkepentingan dalam menjayakan pembelajaran mobil. Tujuan pengkaji 
menentukan kriteria sedemikian adalah untuk memastikan kajian yang dijalankan ini memberi tumpuan kepada kesediaan penggunaan pembelajaran mobil dalam kalangan guru dan pelajar sahaja. Kemudian, artikel jurnal yang berulang dalam kedua-dua pangkalan data dibuang melalui pembacaan tajuk dan abstrak masing-masing. Setelah melakukan saringan, 24 buah artikel yang tidak menepati kriteria kajian dan 66 buah artikel yang berulang disingkirkan. Maka, hanya berbaki sejumlah 48 buah artkel ke fasa selanjutnya.

\section{Kelayakan (Eligibility)}

Sejumlah 48 buah artikel ini disaring semula dengan membaca tajuk, abstrak, metodologi, dapatan dan perbincangan kajian untuk memastikan artikel-artikel tersebut menepati kriteria pemilihan dan tujuan kajian. Kemudian, sejumlah 23 buah artikel telah dibuang pada peringkat ini kerana tidak menghuraikan kesediaan penggunaan pembelajaran mobil dengan terperinci (13 buah), tidak memaparkan dan membincangkan data-data hasil dapatan dengan jelas dalam bahagian dapatan kajian (7 buah) serta fokus kajian lebih menjurus kepada pembinaan model untuk tujuan penilaian kesediaan (3 buah).

\section{Terpilih (Inclusion)}

Akhirnya, hanya terdapat 25 buah artikel yang berbaki dan memenuhi kriteria pemilihan yang ditetapkan dalam kajian ini (Jadual 1).

Rajah 1: Adaptasi dan ubahsuai proses pemilihan artikel daripada Moher et al. (2009).

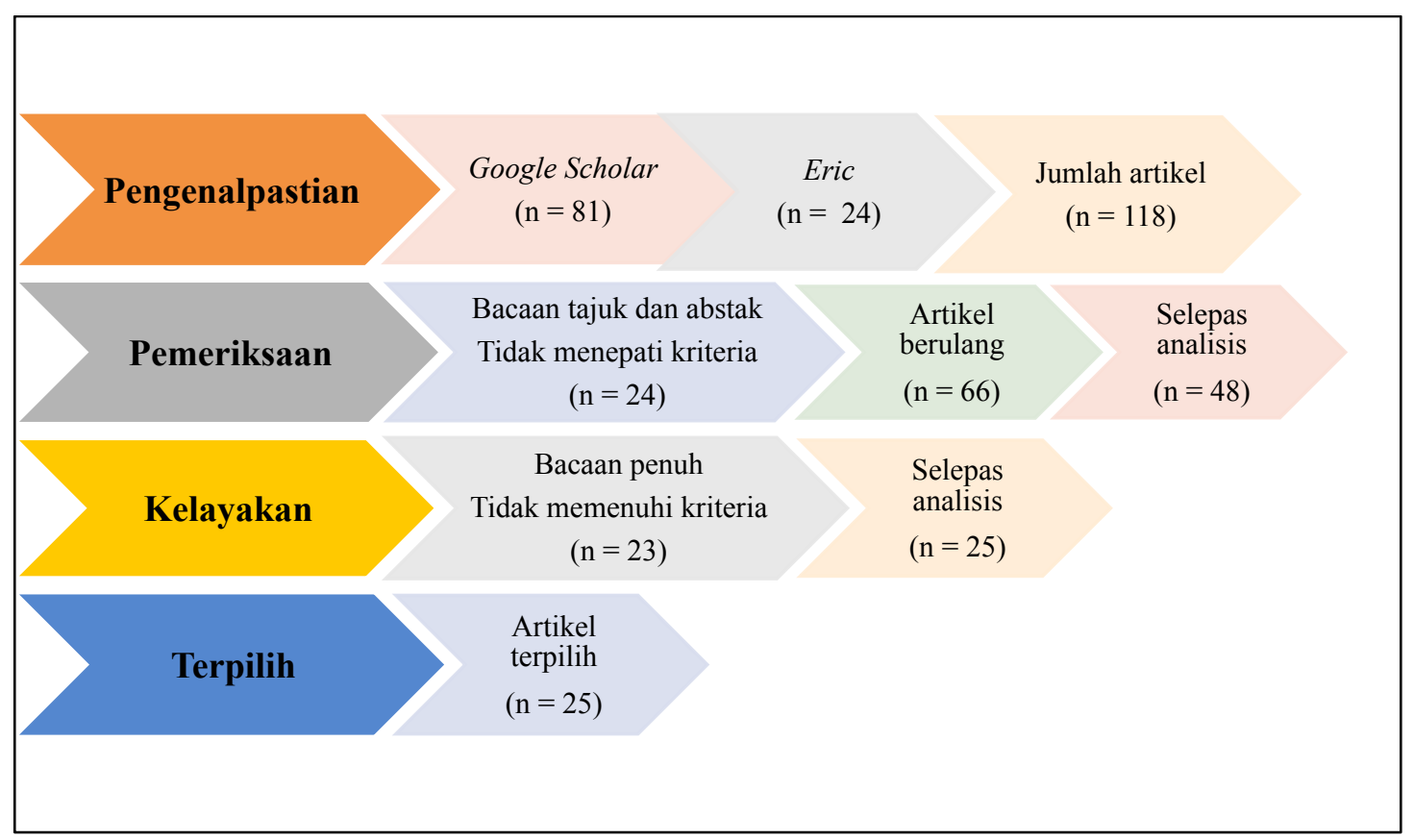

Pengkaji telah mengklasifikasikan 25 buah kajian-kajian terpilih dalam kajian ini ke dalam tiga kumpulan mengikut kaedah penyelidikan yang digunakan. Berdasarkan Jadual 1, hampir semua kajian terpilih adalah kajian kuantitatif, iaitu sebanyak 23 buah kajian. Hanya satu kajian yang mengkaji kesediaan terhadap penggunaan pembelajaran mobil dengan manggunakan kaedah kualitatif dan satu kajian lagi menggunakan kaedah bergabung. Terdapat 16 buah kajian mengkaji kesediaan pelajar terhadap penggunaan pembelajaran mobil manakala jumlah kajian yang meninjau kesediaan guru dalam penerapan pembelajaran mobil adalah sebanyak 6 buah. Di samping itu, terdapat 3 buah kajian yang mengkaji kesediaan mengenai pembelajaran mobil yang melibatkan kedua-dua pihak, iaitu guru dan pelajar (Sharehu \& Emmanuel 2015). 2 daripada 3 buah kajian tersebut turut mengkaji kesediaan pihak pengurusan atau pegawai informasi teknologi, IT (Okai-Ugbaje, Ardzejewska \& Imran 2020; Ruxwana \& Msibi (2018). Kebanyakan lokasi kajian adalah di peringkat pengajian tinggi termasuk kolej, institusi dan universiti. Hanya 2 kajian dibuat di sekolah menengah dan 1 kajian dilakukan di sekolah rendah. 
Jadual 1: Senarai artikel terpilih diklasifikasi berdasarkan kaedah kajian

\begin{tabular}{|c|c|}
\hline \multirow{2}{*}{$\begin{array}{l}\text { Metodologi } \\
\text { Kajian kuantitatif, } n=23\end{array}$} & Pengkaji (Tahun) \\
\hline & $\begin{array}{l}\text { Mutono \& Dagada (2016) } \\
\text { Munir Shuib, Siti Norbaya Azizan \& Malini } \\
\text { Ganapathy (2018) } \\
\text { Iqbal \& Bhatti (2015) } \\
\text { Mohammad Shorfuzzaman \& Musaed Alhussein } \\
\text { (2016) } \\
\text { Malike Brahim \& Musliza Mohamad (2018) } \\
\text { Tagoe \& Abakah (2014) } \\
\text { Chaka \& Govender (2017) } \\
\text { Miglani \& Awadhiya (2017) } \\
\text { Ahmad Sobri Shuib, Muhammad Nidzam Yaakob \& } \\
\text { Azizah Sarkowi (2018) } \\
\text { Soetan \& Coker (2018) } \\
\text { Murugan, Teoh \& Liau (2017) } \\
\text { Ahmad Samed Al-Adwan, Amr Al-Madadha \& } \\
\text { Zahra Zvirzdinaite (2018) } \\
\text { Baş \& Sarigöz (2018) } \\
\text { Meizareena Mizad et al. (2018) } \\
\text { Reddy et al. (2016) } \\
\text { Reddy et al. (2017) } \\
\text { Almutairy, Davies, \& Dimitriadi (2015) } \\
\text { Nazir Ahmad Suhail (2017) } \\
\text { Hafiza Abas, Faridah Hanim Yahya \& Mahamsiatus } \\
\text { Kamaruddin (2015) } \\
\text { Al-Husain \& Hammo (2015) } \\
\text { Aliff Nawi, Mohd Isa Hamzah \& Azwin Arif Abdul } \\
\text { Rahim (2015) } \\
\text { Okai-Ugbaje, Ardzejewska \& Imran (2020) } \\
\text { Moosavi, DeWitt \& Naimie (2018) }\end{array}$ \\
\hline Kajian kualitatif, $n=1$ & Ruxwana \& Msibi (2018) \\
\hline Kajian kaedah bergabung, $\mathrm{n}=1$ & Sharehu \& Emmanuel (2015) \\
\hline
\end{tabular}

\section{Hasil Kajian}

Objektif utama dalam kajian ini adalah untuk mengkaji kesediaan guru dan pelajar terhadap penggunaan pembelajaran mobil dalam pembelajaran dan pemudahcaraan (PdPc) melalui kaedah sorotan litaratur bersistematik. Secara keseluruhan, enam aspek kesediaan telah dikenal pasti mempunyai pengaruh yang signifikan terhadap penggunaan pembelajaran mobil sama ada secara langsung atau secara tidak langsung. Kajian Iqbal dan Bhatti (2015) serta kajian Mutano dan Dagada (2016) mencadangkan kesediaan terhadap penggunaan pembelajaran mobil boleh diukur dalam dua kategori, iaitu kesediaan kemahiran dan kesediaan psikologi. Lanjutannya, kajian Meizareena Mizad et al. (2018) memperkenalkan dua lagi dimensi kesediaan yang dikaji selain daripada kajian kemahiran dan kesediaan psikologi. Dua dimensi kesediaan baru tersebut adalah kesediaan asas atau juga dikenali sebagai kesediaan peranti dalam kajian Miglani dan Awadhiya (2017) serta kesediaan perbelanjaan.

Di samping itu, kajian Ruxwana dan Msibi (2018) pula mengesyorkan kesediaan terhadap penggunaan pembelajaran mobil dinilai dengan berfokus kepada kesediaan pengurusan dan kesediaan teknologi. Satu hasil kajian yang menarik didapati ialah walaupun kajian Murugan, Toeh dan Liau (2017) juga mengkaji kesediaan teknologi dalam penggunaan pembelajaran mobil, tapi bidang kesediaan teknologi yang diselidik adalah berbeza dengan yang dikaji dalam kajian Ruxwana dan Msibi (2018). Murugan, Toeh dan Liau (2017) mendefinisikan bahawa kesediaan 
teknologi adalah kemahiran pelajar dalam mengendalikan fungsi peranti mudah alih mereka untuk tujuan pembelajaran manakala Ruxwana dan Msibi (2018) menekankan ketersediaan infrastruktur teknologi yang sesuai dengan penggunaan pembelajaran mobil. Dengan merujuk kepada kajiankajian lepas tersebut, pengkaji akan menganalisis dan mensintesis kesediaan guru dan pelajar terhadap penggunaan pembelajaran mobil mengikut kategori kesediaan asas, kemahiran, psikologi dan perbelanjaan seperti yang dicadangkan dalam kajian Meizareena Mizad et al. (2018) dalam bahagian yang seterusnya. Kesediaan pengurusan oleh pihak pentadbir tidak dimasukkan dalam skop kajian kerana kajian ini memberi perhatian kepada kesediaan penggunaan pembelajaran mobil dalam kalangan guru dan pelajar sahaja.

\section{Kesediaan Asas}

Kesediaan asas dalam kajian ini memfokuskan pada kesediaan guru dan pelajar terhadap pembelajaran mobil dengan mempertimbangkan kemudahan mudah alih yang dimiliki oleh mereka miliki (Meizareena Mizad et al. 2018). Berdasarkan Jadual 2, sejumlah 16 daripada 25 buah kajian telah meneliti kesediaan asas guru atau pelajar untuk melibatkan diri dalam pembelajaran mobil. Hasil dapatan kajian menunjukkan telefon pintar merupakan peranti mudah alih yang paling popular dan biasa dimiliki oleh guru dan pelajar (14 buah kajian), diikuti dengan laptop atau komputer riba. 6 daripada 14 kajian tersebut mendapati kebanyakan guru dan pelajar menggunakan telefon pintar yang menawarkan perkhidmatan akses internet $3 \mathrm{G}$ atau 4G (Almutairy, Davies, \& Dimitriadi 2015; Hafiza Abas, Faridah Hanim Yahya \& Mahamsiatus Kamaruddin 2015; Meizareena Mizad et al. 2018; Reddy et al. 2016; Tagoe \& Abakah 2014). Selain itu, 2 kajian menunjukkan bahawa telefon pintar Android lebih mendapat sambutan daripada guru dan pelajar berbanding dengan telefon pintar iPhones (Reddy et al. 2016; Reddy et al. 2017). Namun begitu, terdapat satu kajian yang mendapati paling banyak pelajar menggunakan komputer riba (Al-Husain \& Hammo 2015). Satu lagi kajian pula menunjukkan majoriti guru dan pelajar menggunakan handsets untuk tujuan pembelajaran mobil berbanding dengan telefon pintar dan iPads (Sharehu \& Emmanuel 2015).

Jadual 2: Senarai kajian berkaitan kesediaan asas berdasarkan kemudahan mudah alih dimiliki

\begin{tabular}{ll}
\hline Kemudahan mudah alih & Pengkaji (Tahun) \\
\hline Telefon pintar, $\mathrm{n}=14$ & Munir Shuib, Siti Norbaya Azizan \& Malini Ganapathy (2018) \\
& Iqbal \& Bhatti (2015) \\
& Tagoe \& Abakah (2014) \\
& Miglani \& Awadhiya (2017) \\
& Ahmad Samed Al-Adwan, Amr Al-Madadha \& Zahra \\
& Zvirzdinaite (2018) \\
& Meizareena Mizad et al. (2018) \\
& Reddy et al. (2016) \\
& Reddy et al. (2017) \\
& Almutairy, Davies \& Dimitriadi (2015) \\
& Nazir Ahmad Suhail (2017) \\
& Hafiza Abas, Faridah Hanim Yahya \& Mahamsiatus \\
& Kamaruddin (2015) \\
& Aliff Nawi, Mohd Isa Hamzah \& Azwin Arif Abdul Rahim \\
& $(2015)$ \\
\hline Al-Husain \& Hammo (2015) \\
\hline Handsets, $\mathrm{n}=1$ & Sharehu \& Emmanuel (2015) \\
\hline
\end{tabular}

\section{Kesediaan Kemahiran}

Kesediaan kemahiran dinilai berdasarkan aktiviti yang dilakukan (Miglani \& Awadhiya 2017) melalui kemudahan mudah alih terutamanya telefon pintar. Dengan merujuk kepada Jadual 3, sejumlah sebelas jenis aktiviti pembelajaran yang dilakukan oleh guru dan pelajar dengan 
DOI: https://doi.org/10.47405/mjssh.v5i10.513

mengggunakan kemudahan mudah alih masing-masing telah dikenal pasti. Antaranya termasuklah penghantaran mesej teks atau mesej audio (6 kajian), membuat panggilan (4 kajian), memuat naik atau memuat turun bahan pembelajaran dan berkongsi e-kandungan multimedia ( 3 kajian), membincang, menyelesaikan dan menyemak tugasan (3 kajian), membaca e-buku, berita dalam talian dan dokumen ( 3 kajian), mendapatkan maklum balas daripada guru atau rakan (2 kajian), persidangan web dan interaksi pengajaran dan pembelajaran (2 kajian), menghantar dan menerima emel ( 2 kajian), melayari laman web pendidikan dan mencari maklumat (2 kajian), guna kamera digital untuk menyalin jadual waktu dan aktiviti mingguan (1 kajian) serta berkongsi sambungan internet dari telefon pintar ke komputer atau komputer riba (1 kajian).

Jadual 3: Senarai kajian tentang kesediaan kemahiran berdasarkan aktiviti pembelajaran dibuat

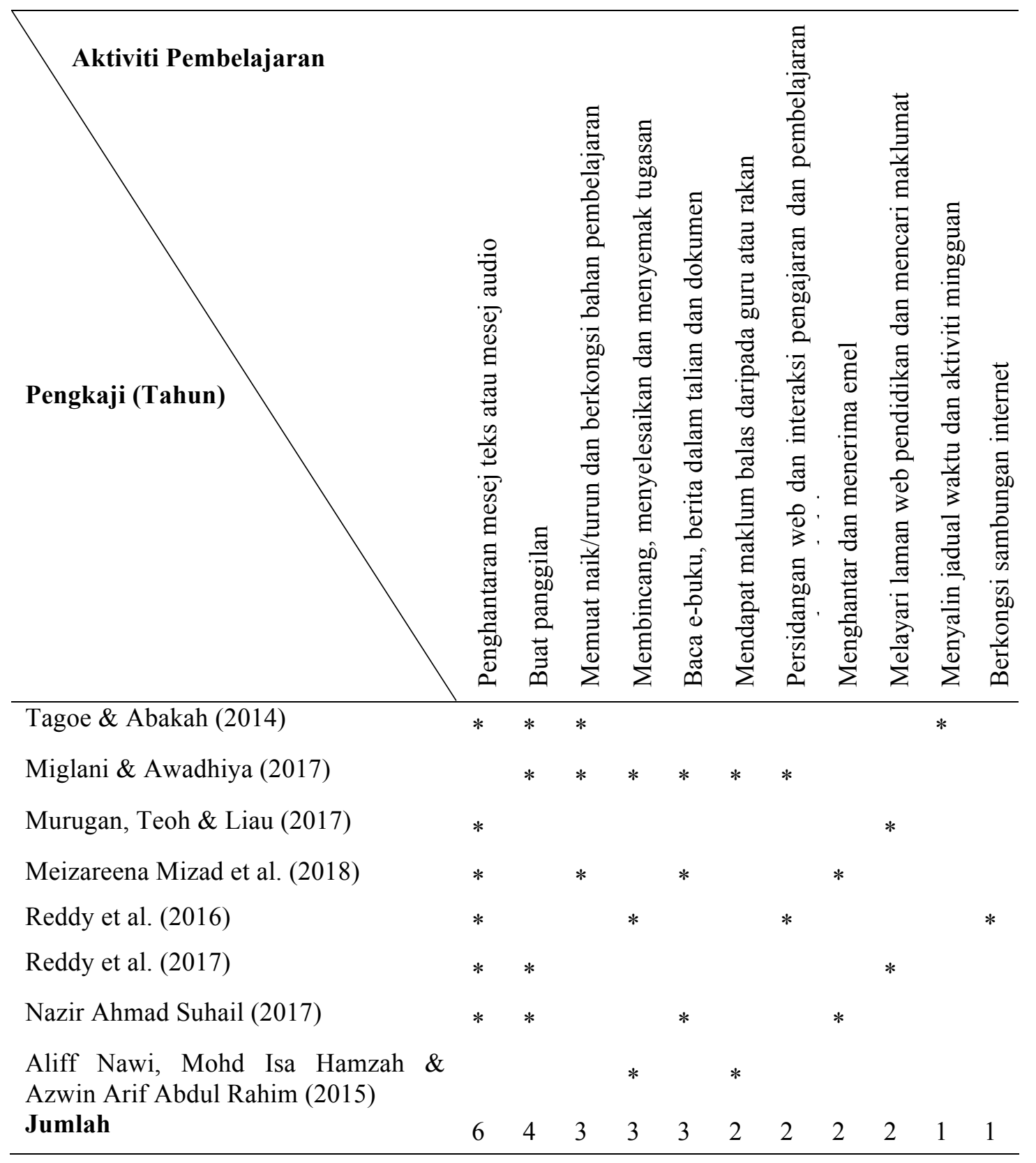

\section{Kesediaan Psikologi}

Bagi memastikan pembelajaran mobil dapat diterima dengan baik oleh guru dan pelajar, kesediaan psikologi mereka tentang pembelajaran mobil secara persepsi dan perasaan perlu 
DOI: https://doi.org/10.47405/mjssh.v5i10.513

dipertimbangkan. Dapatan kajian-kajian lepas menunjukkan kesediaan psikologi guru dan pelajar terhadap pembelajaran mobil boleh dikategorikan kepada psikologi positif dan psikologi negatif. Terdapat sembilan psikologi positif yang dikenal pasti merangkumi persepsi beranggapan bahawa pembelajaran mobil dengan megaplikasikan teknologi mudah alih adalah mudah digunakan (11 kajian), sangat berguna dan produktif (13 kajian), fleksibiliti dari segi masa dan tempat ( 8 kajian), inovatif (1 kajian) serta kolaboratif (4 kajian) selain berasa optimism (2 kajian), menyeronokkan (4 kajian), memotivasikan (3 kajian) dan berkeyakinan diri (1 kajian). Kesediaan psikologi positif paling kerap dibentang akan kegunaan pembelajaran mobil, diikuti dengan kesenangan dimanipulasi dan kemudahan mengakses tanpa sekatan masa serta tempat. Sementara itu, dua psikologi negatif yang dikesan daripada dapatan kajian mengandungi perasaan ketidakselesaan (1 kajian) kerana peranti boleh dilihat oleh orang lain dan rasa tidak selamat (1 kajian) terhadap isu pengintipan maklumat yang dihantar. Jadual 4 memaparkan ringkasan dapatan kajian berkaitan kesediaan psikologi guru dan pelajar terhadap pembelajaran mobil sama ada mempunyai psikologi positif atau psikologi negatif.

Jadual 4: Ringkasan dapatan kajian tentang kesediaan psikologi terhadap pembelajaran mobil

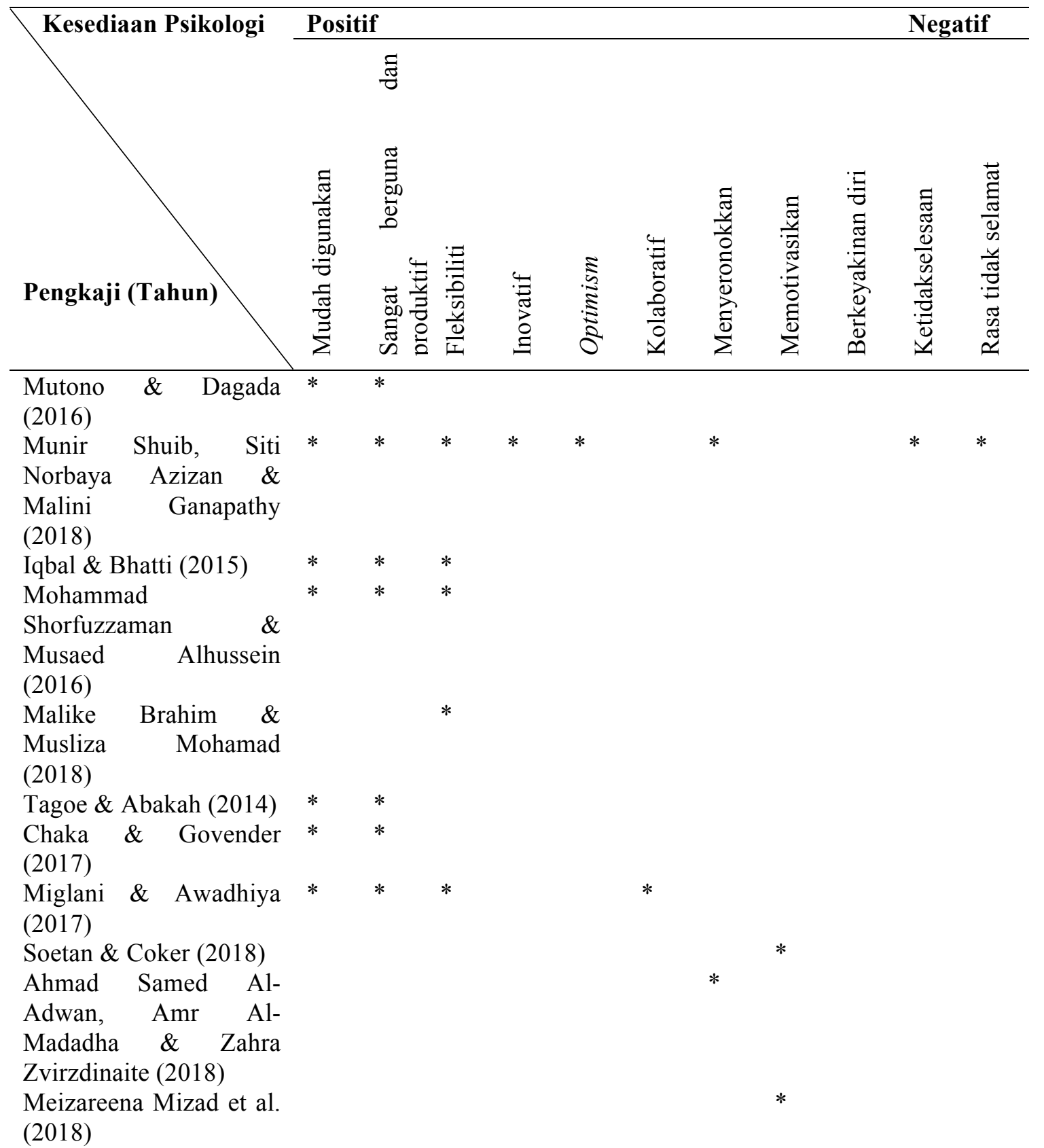


Reddy et al. (2016)

Reddy et al. (2017)

Almutairy, Davies \&

Dimitriadi (2015)

Nazir Ahmad Suhail

(2017)

Hafiza Abas, Faridah

Hanim Yahya \&

Mahamsiatus

Kamaruddin (2015)

Al-Husain \& Hammo

(2015)

Okai-Ugbaje,

Ardzejewska \& Imran

(2020)

Moosavi, DeWitt \& * * * *

Naimie (2018)

\begin{tabular}{llllllllllll}
\hline Jumlah & 11 & 13 & 8 & 1 & 4 & 2 & 4 & 3 & 1 & 1 & 1 \\
\hline
\end{tabular}

\section{Kesediaan Perbelanjaan}

Penggunaan kemudahan mudah alih untuk aktiviti pembelajaran akan membebankan pengguna. Oleh itu, kesediaan guru dan pelajar terhadap pengintegrasian pembelajaran mobil dari segi kesediaan perbelanjaan dianalisis dalam kajian ini. Kajian-kajian literatur yang mengkaji tentang kesediaan perbelanjaan adalah paling sedikit antara empat aspek kesediaan yang diselidik dalam kajian ini di mana hanya terdapat lima buah kajian yang meninjau kemampuan kewangan pengguna pembelajaran mobil. 1 daripada 5 buah kajian tersebut menerangkan kesediaan perbelanjaan guru terhadap penggunaan teknologi mudah alih dalam aktiviti pembelajaran manakala 4 lagi buah kajian menghuraikan kesediaan kewangan pelajar. Dapatan kajian menunjukkan bahawa pendapatan bulanan tidak menjejaskan kesediaan guru pra perkhidmatan terhadap pembelajaran mobil (Baş \& Sarıgöz 2018). Akan tetapi, dari perspektif pelajar pula, kesediaan perbelanjaan mereka adalah pada tahap tidak pasti (Meizareena Mizad et al. 2018). Mereka belum sedia untuk menanggung kos tambahan seperti kos data mobil untuk pembelajaran (Okai-Ugbaje, Ardzejewska \& Imran 2020; Reddy et al. 2016). Walau bagaimanapun, kajian juga mendapati bahawa pelajar berminat untuk memiliki satu peranti mudah alih baru yang dilengkapi dengan ciri-ciri lebih maju agar proses pembelajaran mobil dapat dijalankan dengan lancar (Almutairy, Davies \& Dimitriadi 2015). Jadual 5 menunjukkan senarai kajian mengenai kesediaan perbelanjaan guru dan pelajar bagi melaksanakan pembelajaran mobil.

Jadual 5: Senarai kajian berkaitan kesediaan perbelanjaan guru dan pelajar

\begin{tabular}{ll}
\hline Kesediaan Perbelanjaan & Pengkaji (Tahun) \\
\hline Guru, $\mathrm{n}=1$ & Baș \& Sarı̈öz 2018 \\
\hline Pelajar, $\mathrm{n}=4$ & Meizareena Mizad et al. 2018 \\
& Reddy et al. 2016 \\
& Almutairy, Davies \& Dimitriadi 2015 \\
& Okai-Ugbaje, Ardzejewska \& Imran 2020 \\
\hline
\end{tabular}

\section{Perbincangan Kajian}

Perbincangan ini dibuat berasaskan isu-isu teoritikal dan metodologikal. Dapatan kajian telah membekalkan input mengenai beberapa isu teori dalam pengintegrasian teknologi mudah alih bagi menjalankan pembelajaran mobil. Kajian oleh Mutono dan Dagada (2016) serta kajian oleh Iqbal dan Bhatti (2015) menggunakan Technology Acceptance Model (TAM) sebagai teori utama. Kajian 
Mohammad Shorfuzzaman dan Musaed Alhussein (2016) dan kajian Tagoe dan Abakah (2014) menyiasat penggunaan pembelajaran mobil dengan mengguna pakai Unified Theory of Acceptance and Use of Technology Model (UTAUT). Dalam pada itu, kajian Mohammad Shorfuzzaman dan Musaed Alhussein (2016) telah membuat pengadaptasian terhadap model UTAUT dengan menggantikan fakor penyederhanaan jantina, umur, pengalaman dan kesukarelaan dengan memperkenalkan dua faktor penyederhanaan, iaitu kreativiti pelajar dan mobiliti.

Terdapat juga kajian yang mengaplikasikan Theory of Planned Behaviour (TPB) bagi meninjau kesediaan pelajar universiti berkenaan penggunaan teknologi mobil dalam proses pembelajaran, iaitu kajian Tagoe dan Abakah (2014) serta kajian Moosavi, DeWitt dan Naimie (2018). Hanya satu kajian dari Munir Shuib, Siti Norbaya Azizan dan Malini Ganapathy (2018) mengkaji kesediaan pelajar terhadap penerapan pembelajaran mobil dengan mengadaptasikan Parasuraman's Technology Readiness Index (TRI). Selain itu, kajian oleh Ruxwana dan Msibi (2018) telah menggabungkan teori teknologi-organisasi- persekitaran (TOE) (Tornatzky \& Fleischer 1990) bersama dengan teori difusi inovasi (DOI) (Rodgers 2003).

Di samping itu, kajian-kajian yang mengaplikasikan model TAM, UTAUT dan TPB telah membincangkan integrasi teknologi mudah alih dalam dengan mengaitkan kesediaan pelajar dengan persepsi mereka terhadap kesenangan pembelajaran mobil (perceived ease of use) digunakan dan kegunaan pembelajaran mobil (perceived usefulness).

Secara metodologi, isu yang dapat diperihalkan bergantung pada kaedah kajian. Jumlahnya sebanyak 23 dari 25 buah kajian yang dianalisis dalam kajian ini menggunakan kaedah kuantitatif, satu kajian sahaja yang menggunakan kaedah kualitatif dan kaedah bergabung masing-masing. Sehubungan dengan itu, boleh dirumuskan bahawa kebanyakan kajian menggunakan kaedah kuantitatif. Perkara ini disebabkan oleh para penyelidik pada masa lalu telah menemui hubungan antara kesediaan dan penggunaan teknologi di antara pembolehubah yang telah dinyatakan. Menurut Creswell (2014), kaedah kuantitatif adalah kaedah yang paling disukai untuk digunakan dalam kalangan penyelidik sains sosial semasa mengkaji hubungan antara pembolehubah.

\section{Kesimpulan}

Sorotan literatur bersistematik ini dibuat bertujuan untuk meneliti isu berkaitan kesediaan guru dan pelajar terhadap penggunaan pembelajaran mobil dari aspek kesediaan asas, kesediaan kemahiran, kesediaan psikologi dan kesediaan perbelanjaan. Hasil analisis 25 buah kajian lepas terpilih dalam kajian ini menunjukkan bahawa majoriti guru dan pelajar mempunyai teknologi mudah alih dan bersedia untuk menjalankan pembelajaran mobil. Mereka mempunyai kemahiran mengaplikasikan teknologi mudah alih bagi melakukan aktiviti pembelajaran. Kebanyakan guru dan pelajar mempunyai kesediaan psikologi yang positif terhadap penggunaan pembelajaran mobil. Akan tetapi, terdapat sebahagian pelajar yang berasa tidak selesa dan tidak selamat mengenai kaedah pembelajaran mobil kerana mudah terdedah kepada isu pengintipan maklumat. Bukan itu sahaja, terdapat pelajar yang kurang bersedia dari segi kewangan bagi menanggung kos tambahan seperti kos data mobil untuk pembelajaran. Perkara ini menunjukkan bahawa pembelajaran mobil masih sangat baru dan belum berkembang menjadi matang. Maka, penggunaan pembelajaran mobil dalam bidang pendidikan seharusnya dirancang dan dilaksanakan secara berhati-hati.

\section{Rujukan}

Ahmad Samed Al-Adwan, Amr Al-Madadha \& Zahra Zvirzdinaite. (2018). Modeling students' readiness to adopt mobile learning in higher education: An empirical study. International Review of Research in Open and Distributed Learning, 19(1), 221-241. 
Ahmad Sobri Shuib, Muhammad Nidzam Yaakob \& Azizah Sarkowi. (2018). Pengaruh pengalaman teknologi, peluang dan kesediaan terhadap penggunaan mobile learning di institut pendidikan guru zon utara. Jurnal Penyelidikan Dedikasi, 14, 143-166.

Al-Husain, Dalal., \& Hammo, B. H. (2015). Investigating the readiness of college students for ict and mobile learning: A case study from king saud university. International Arab Journal of eTechnology, 4(1), 48-55.

Aliff Nawi, Mohd Isa Hamzah \& Azwin Arif Abdul Rahim. (2015). Teachers acceptance of mobile learning for teaching and learning in islamic education: A preliminary study. Turkish Online Journal of Distance Education, 16(1), 184-192.

Almutairy, S., Davies, T., \& Dimitriadi, Y. (2015). Students' perceptions of their m-learning readiness. Journal of Electronics and Communication Engineering, 9(5), 1464-1467.

Arlina Ahmad Zaki. \& Melor Yunus. (2015). Potential of mobile learning in teaching of esl academic writing. Canadian Center of Science and Education, 8(6), 11-19.

Baş, M., \& Sarıöz, O. (2018). Determining the readiness levels of pre-service teachers towards mobile learning in classroom management. Education Research and Reviews, 13(10), 382-390.

Chaka, J. G., \& Govender, I. (2017). Students' perceptions and eadiness towards mobile learning in colleges of education: A nigerian perspective. South African Journal of Education, 37(1), 1-12.

Chen, C. H., Chiu, C. H., Lin, C. P., \& Chou, Y. C. (2017). Students' attention when using touchscreens and pen tablets in a mathematics classroom. Journal of Information Technology Education: Innovations in Practice, 16, 91-106.

Creswell, J. W. (2014). Research design: Qualitative, quantitative, and mixed methods approaches (4th ed.). Thousand Oaks, CA: Sage Publications.

Ghavifekr, S., \& Mohammed Sani. (2015). Effectiveness of ICT integration in Malaysian schools: A quantitative analysis. International Research Journal for Quality in Education, 2(8), 1-12.

Ghavifekr, S., Kunjappan, T., Ramasamy, L., \& Anthony, A. (2016). Teaching and learning with ICT tools: Issues and challenges from teachers' perceptions. Malaysian Online Journal of Educational Technology, 4(2), 38-57.

Hafiza Abas, Faridah Hanim Yahya \& Mahamsiatus Kamaruddin. (2015). User readiness evaluation of $\mathrm{qr}$ codes in mobile learning (m-Learning). Proceeding of International Conference on Information Technology \& Society, 126-136.

Iqbal, S., \& Bhatti, Z. A. (2015). An investigation of university student readiness towards m-learning using technology acceptance model. International Review of Research in Open and Distributed Learning, 16(4), 83-103.

Kamus Dewan. (2007). Edisi keempat. Kuala Lumpur: Dewan Bahasa dan Pustaka.

Kementerian Pendidikan Malaysia. (2016). Kurikulum Standard Sekolah Rendah: Dokumen Standard Kurikulum dan Pentaksiran Matematik Tahun 2. Putrajaya: Kementerian Pendidikan Malaysia.

Khoo, Y. Y., \& Fitzgerald, R. (2015). Pocket learning: A new mobile learning approach for distance learners. International Journal of Mobile Learning and Organisation, 9(3), 271-283.

Malike Brahim \& Musliza Mohamad. (2018). Awareness, readiness and acceptance of the students' in polytechnic of sultan abdul halim mu'adzam shah on m-learning. Asian Journal of Sociological Research, 1(1), 21-33.

Meizareena Mizad, Zailin Shah Yusoff, Zainal Abidin Sayadi, Azmi Abdul Latif \& Safra Liyana Sukiman. (2018). Students readiness and motivation to use mobile phone for learning english at higher learning institution. International Journal of Asian Social Science, 8(11), 1077-1087.

Miglani, A., \& Awadhiya, A. K. (2017). Mobile learning: Readiness and perceptions of teachers of open universities of commonwealth asia. Journal of Learning for Development, 4(1), 58-71.

Mohammad Shorfuzzaman \& Musaed Alhussein. (2016). Modeling learners' readiness to adopt mobile learning: A perspective from a gcc higher education institution. Mobile Information System, 2016(3), 1-10.

Moher, D., Liberati, A., Tetzlaff, J., \& Altman, D. G. (2009). Preferred reporting items for systematic reviews and meta-analyses: The prisma statement. Journal of Clinical Epidemiology. 62: 10061012. https://doi.org/10.1016/j.jclinepi.2009.06.005

Moosavi, Z. H., DeWitt, D., \& Naimie, Z. (2018). EFL undergraduate learners' readiness towards mobile learning. Proceeding of the 4th International Conference on Education, 4(2), 121-128. 
Munir Shuib, Siti Norbaya Azizan \& Malini Ganapathy. (2018). Mobile learning readiness among english language learners in a public university in malaysia. Pertanika Journals, 26(3), 14911504 .

Murugan, A., Teoh, G. B. S., \& Liau, A. W. L. (2017). Technological readiness of uitm students in using mobile phones in the english language classroom. Malaysian Online Journal of Educational Technology, 5(2), 34-50.

Mutono, A., \& Dagada, R. (2016). An investigation of mobile learning readiness for post-school education and training in south africa using the technology acceptance model. International Journal of Education and Research, 4(9), 353-366.

Nazir Ahmad Suhail. (2017). Exploring mobile phone usage at higher education: A case study of kampala university, uganda. International Journal of Computer Applications, 170(2), 30-34.

Nurul Aisyah Kamrozzaman, Jamaludin Badusah \& Wan Muna Ruzanna Wan Mohammad. (2019). Pendekatan heutagogi: Keberkesanan m-pembelajaran untuk pendidikan sepanjang hayat. Sains Humanika: Research, 11(3), 53-61.

Okai-Ugbaje, S., Ardzejewska, K., \& Imran, A. (2020). Readiness, roles, and responsibilities of stakeholders for sustainable mobile learning adoption in higher education. Education Sciences, 10(49), 1-21.

Papadakis, S. (2018). The use of computer games in classroom environment. International Journal of Teaching and Case Studies, 9(1), 1-25.

Reddy, E., Sharma, B., Reddy, P., \& Reddy, K. (2016). Student readiness and perception to the use of smart phones for higher education in the pacific. 2016 3rd Asia-Pacific World Congress on Computer Science and Enginerring, 258-264.

Reddy, E., Sharma, B., Reddy, P., \& Dakuidreketi, M. (2017). Mobile learning readiness and ict competency: A case study of senior secondary school students in the pacific islands, 2017 th Asia-Pacific World Congress on Computer Science and Enginerring, 137-143.

Rung, A., Warnke, F., \& Mattheos, N. (2014). Investigating the use of smartphones for learning purposes byaustralian dental students. JMIR Mhealth and Uhealth, 2(2), 1-8.

Ruxwana, N., \& Msibi, M. (2018). A south african university's readiness assessment for bringing your own device for teaching and learning. South African Journal of Information Management, 20(1), 1-6.

Sharehu, A. L., \& Emmanuel, A. E. (2015). Readiness of teachers and pupils for use of mobile devices as support for effective pedagogy in nigeria: Could location be a major determinant?. Online Journal of Distance Learning Administartion, 18(3), 1-13.

Soetan, A. K., \& Coker, A. D. (2018). 'University lecturers' readiness and motivation in utilising online technologies for instructional delivery in kwara state, nigeria. World Journal on Educational Technology: Current Issues, 10(4), 1-15.

Suruhanjaya Komunikasi dan Multimedia Malaysia. (2018). Internet Users Survey 2018: Statistical Brief Number Twenty-three. Selangor Darul Ehsan: Malaysian Communications and Multimedia Commission

Tagoe, M., \& Abakah, E. (2014). Determining distance education students' readiness for mobile learning at university of ghana using theory of planned behavior. International Journal of Education and Development using Information and Communication Technology, 10(1), 99-106. 